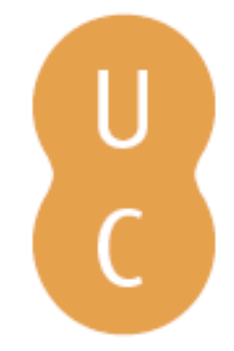

\title{
Rnmbalina
}

\section{A República e o movimento da educação nova no Brasil e em Portugal: sujeitos, concepções e experiências}

\author{
Autor(es): $\quad$ Xavier, Libânia \\ Publicado por: Imprensa da Universidade de Coimbra \\ URL \\ persistente: URI:http://hdl.handle.net/10316.2/35878 \\ DOI: $\quad$ DOI:http://dx.doi.org/10.14195/978-989-26-0862-4_11 \\ Accessed : $\quad$ 26-Apr-2023 07:04:01
}

A navegação consulta e descarregamento dos títulos inseridos nas Bibliotecas Digitais UC Digitalis, UC Pombalina e UC Impactum, pressupõem a aceitação plena e sem reservas dos Termos e Condições de Uso destas Bibliotecas Digitais, disponíveis em https://digitalis.uc.pt/pt-pt/termos.

Conforme exposto nos referidos Termos e Condições de Uso, o descarregamento de títulos de acesso restrito requer uma licença válida de autorização devendo o utilizador aceder ao(s) documento(s) a partir de um endereço de IP da instituição detentora da supramencionada licença.

Ao utilizador é apenas permitido o descarregamento para uso pessoal, pelo que o emprego do(s) título(s) descarregado(s) para outro fim, designadamente comercial, carece de autorização do respetivo autor ou editor da obra.

Na medida em que todas as obras da UC Digitalis se encontram protegidas pelo Código do Direito de Autor e Direitos Conexos e demais legislação aplicável, toda a cópia, parcial ou total, deste documento, nos casos em que é legalmente admitida, deverá conter ou fazer-se acompanhar por este aviso.

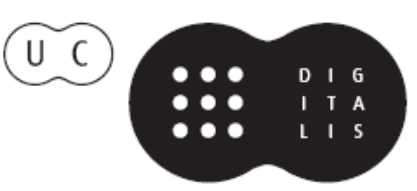




\title{
A EXPERIÊNCIA DA PRIMEIRA REPÚBLICA NO BRASIL E EM PORTUGAL
}

\author{
ALDA MOURÃO \\ ANGELA DE CASTRO GOMES
}

COORDENAÇÃO 


\section{A República e o movimento da educação nova no Brasil e em Portugal: sujeitos, concepçôes e experiências}

Libânia Xavier

ESTE TEXTO ABORDA A IMPORTÂNCIA ATRIBUÍDA À EDUCAÇÃO ESCOLAR NO regime republicano, destacando as proximidades existentes entre o ideário republicano e as concepçóes e experiências que caracterizaram o movimento da educação nova no início do século XX, no Brasil e em Portugal.

No Dicionário de política coordenado por Bobbio, Mateucci e Pasquino (1991), a definição do termo República se faz, antes de tudo, em contraposição ao termo Monarquia. Por essa via, se faz a distinção entre uma e outra forma de Estado, construindo, na confrontação entre esses modelos de organização política, os aspectos positivos que marcam o regime republicano.

No Brasil, o Estado monárquico se apoiou na classe senhorial que se formou em torno à Corte, numa política de concessóes e privilégios; na economia escravista que negava o estatuto de cidadania a grande parte da população; e no regime de Padroado, que implicou a presença do clero no aparelho de Estado, promovendo uma mescla entre as instâncias religiosa e política.

A proclamação da República no Brasil, em 1889, aprofundou as transformaçōes já em curso na segunda metade do século XIX e que se faziam sentir nos esforços de modernização urbana, inclusive com a construção dos primeiros prédios escolares por iniciativa do governo monárquico, a despeito da inexistência de um setor político em nível nacional que respondesse pela escolarizaçáo do povo.

A generalização dos grupos escolares pelo território nacional forneceu as bases materiais e simbólicas do projeto republicano de modernização do país pela educaçáo do povo. Foi a partir do advento da República que a preocupa- 
ção com a materialidade da educação pública se concretizou, com um amplo programa de construçóes escolares como decorrência das reformas educacionais nos estados, culminando com a criação do Ministério da Educação e Saúde, em 1931. Desse modo, se tornou possível estabelecer as bases necessárias ao controle e à supervisão das iniciativas dos entes federados no que tange à estruturação e à expansão dos sistemas estaduais e municipais de ensino.

Por seu turno, a separação entre Igreja e Estado, operada com a proclamação da República, paralelamente à expansão do movimento da educação nova, exerceu forte influência sobre a formulação de uma concepção acerca do papel da educação como instrumento de democratização da sociedade. A escola laica se colocou então como garantia de construção da escola comum ou única, acessível a todos.

No âmbito da organizaçáo política, a República estabeleceu o governo constitucional e representativo, apoiado no voto universal, masculino e alfabetizado. Tais imperativos postos em um país como o Brasil, de base rural, com uma população de maioria analfabeta (cerca de $75 \%$ da população adulta), teve desdobramentos nas campanhas cívicas e nacionalistas, entre as quais se destacam as campanhas de combate ao analfabetismo, descrito por uns como vergonha nacional e considerado por outros um impeditivo à participação popular nas eleiçóes e, portanto, obstáculo à plena efetivação do ideal republicano. Ao lado da preocupação com o analfabetismo, a educação elementar e, depois, a escola primária de caráter popular ocuparam as atençóes dos intelectuais e políticos republicanos que atuaram nas primeiras décadas do século XX.

Em Portugal, como assinala Costa Pinto (2005:13), a ideologia republicana portuguesa foi fundamentalmente subsidiária da terceira república francesa, abraçando as bandeiras do sufrágio universal masculino, a secularizaçáo da educação, a autonomia municipal e a radical separação da Igreja e do Estado como elementos centrais da propaganda republicana. $\mathrm{O}$ autor observa, ainda, que, às vésperas da Revolução de 1910, o Partido Republicano possuía um programa extremamente flexível, explorando temas como o nacionalismo, o anticlericalismo, o alargamento da participaçáo política, o direito à greve e ouras reivindicaçóes do frágil movimento operário. Complementando o diagnóstico da sociedade portuguesa da época em que se deu a derrubada da monarquia e a implantação da República, cabe registrar que, em 1911, cerca de $70 \%$ da populaçáo com mais de sete anos era analfabeta. 
A Constituição de 1911 adotou o voto universal masculino e alfabetizado, mantendo bastante reduzida a participação política, sendo o período caracterizado pela estabilidade eleitoral e pela instabilidade governamental, o que certamente interferiu na implementação de reformas educacionais em nível nacional.

Por fim, é relevante assinalar a proximidade percebida entre o republicanismo e as ideias de modernidade, tanto no âmbito da organização política e econômica quanto no âmbito da educaçáo e da cultura. A ambiência republicana, em ambos os países, alimentou os anseios de inovação em geral, e de renovação pedagógica em particular, configurando o movimento que ficou conhecido como movimento da educação nova.

O referido movimento se expressou por meio de um conjunto de experiências educativas levadas a efeito em diferentes países do mundo ocidental cujo denominador comum se encontrava em concepçóes, por assim dizer, inovadoras a respeito da educação das crianças. Este mix de experiências e concepçóes orientadoras configurou um movimento internacional que teve presença marcante no cenário intelectual de fins do XIX e início do século XX.

Tais concepçóes se formalizaram em oposição ao modelo educacional forjado ao longo do século XIX, acompanhando a emergência de novos modos de governo e a afirmação dos Estados nacionais. Nesse modelo, a escola transformou-se num elemento central do processo de homogeneizaçáo cultural e de invenção de uma cidadania nacional, contemplando a necessidade de enquadramento escolar a todos. Desse modo, a consolidação dos Estados nacionais se dá em paralelo com um dado modelo escolar que é difundido em nível mundial, alcançando estabilidade e permanência surpreendentes.

Como observou Antonio Nóvoa (1995:26), o desenvolvimento da escola de massas fez parte de uma dinâmica transnacional que inscreveu, nos diversos contextos nacionais, racionalidades e tecnologias de progresso difundidas em nível mundial e que se fundaram em uma base tríplice, marcada: 1) pelo reforço do papel do Estado na área da educaçáo; 2) pela afirmaçáo coletiva dos professores em termos de seu estatuto profissional; 3) pelos esforços de cientificizaçáo da pedagogia, a serem lidos em paralelo com a produçáo dos discursos das ciências sociais e humanas.

Cabe assinalar, com este autor, que o modelo de organização escolar que entáo se consolidou teve como base um conjunto de procedimentos e de ra- 
cionalidades pautados em técnicas de homogeneização do modo de organização e funcionamento das instituiçóes educativas. Deste modelo institucional derivaram processos de homogeneização cultural pela disseminação de normas de comportamento, de hábitos e valores capazes de construir consensos políticos, sociais e individuais. E será contra esse modelo padronizado e naturalizado pelas e nas escolas que o movimento da educação nova irá definir suas bandeiras e seus programas de ação.

Assim, o movimento da educação nova se definiu por oposição à escola tradicional, defendendo um modelo alternativo de organização escolar, atento às características individuais de seus alunos e, ao mesmo tempo, aberto às questôes presentes no meio social circundante. Tais propósitos incidiram sobre a configuração dos conteúdos de ensino, bem como sobre as atividades didáticas, propugnando métodos ativos de aprendizagem, desenvolvidos individual e coletivamente, orientados pelas preocupaçóes em fluxo na vida social e se beneficiando dos avanços alcançados pelas ciências em geral.

"Nunca ninguém desconfiou tanto da escola e nunca ninguém acreditou tanto na escola como os grupos que deram corpo e voz à Educaçáo Nova." Com esta frase, Nóvoa (1995:31) nos leva a refletir sobre os limites da crítica que o movimento da educaçáo nova dirigiu à escola tradicional, bem como sobre as potencialidades das inovaçóes sugeridas. Nessa linha, somos levados a reconhecer que as lideranças do referido movimento aprofundaram as três lógicas mencionadas - estatização, profissionalização e cientificização - no contexto de crença total nas potencialidades regeneradoras da escola, mas, também, atuou segundo os limites das concepçóes e experiências possíveis na sociedade da época.

Por outro lado, o movimento da educação nova foi impulsionado pelo intercâmbio intelectual promovido em diferentes frentes, tais com a formação da Liga Internacional da Educação Nova e associaçóes nacionais similares em diferentes países, por meio de congressos, da circulação de impressos, de viagens oficiais, assim como pela implementação de escolas experimentais, de políticas inovadoras e outras iniciativas pertinentes aos princípios e objetivos do movimento. ${ }^{1}$ Nesse aspecto, interessa destacar justamente o propósito de

\footnotetext{
${ }^{1}$ No Brasil, a Associação Brasileira de Educaçáo (ABE), fundada em 1924, desempenhou o papel de propulsora do debate educacional, congregando as diversas correntes pedagógicas existentes, inclusive os educadores filiados ao movimento da educação nova. Sobre o assunto, ver Carvalho (1998). Existe,
} 
construir uma escola renovada segundo as transformações políticas operadas no período, o que implicou a construção de uma nova imagem do professor e do aluno, assim como uma nova definição a respeito do papel da educação e da escola na sociedade. Não por acaso, os experimentos ligados a este movimento alcançaram grande desenvolvimento com a implantação do regime republicano em países como o Brasil e Portugal, embora não só nestes.

Consoante um modelo de sociedade e de cidadão que atendesse às demandas da sociedade moderna em processo de expansão, a educação nova abraçou as bandeiras republicanas fundadas na defesa da laicidade do Estado e da escola; na participação ativa dos cidadãos nos processos políticos e, em particular, nos processos eleitorais; na responsabilidade do Estado para com a universalização do ensino e o enquadramento de todos os cidadãos no universo da cultura racional letrada; aliados a uma promessa de progresso social gradual, vista por muitos como possibilidade de redenção social.

\section{O movimento da educação nova em Portugal}

Em artigo intitulado História das inovaçôes educativas (1875-1936), Rogério Fernandes (1993) definiu o termo inovaçôes pedagógicas no âmbito de duas grandes áreas que englobavam: 1) ensaios de modernização ou reformas efetivas de um dado sistema educativo e 2) projetos e movimentos pedagógicos alternativos, assim como as concepçóes de seus protagonistas ou, ainda, o estudo das intervençóes realizadas por instituiçóes específicas. Desse modo, o autor sublinha a convergência entre inovação pedagógica e o projeto social e educativo que o sustenta, assinalando a estreita relação entre inovação e contestação com o institucionalmente consagrado.

No caso português, o autor assinala a ocorrência, já em fins do século XIX, de iniciativas educacionais, notadamente em instituiçôes privadas de ensino, que marcaram uma distância crítica em relação ao ensino oficial. Já no início do século XX, ampliam-se as expectativas de renovação da escola em diferentes

ainda, uma extensa bibliografia sobre os diferentes modos de apropriação do movimento da educação nova nos estados e regióes brasileiros. Sobre os Congressos da Liga Nacional de Instrução, realizados em Lisboa, entre 1908 e 1914, ver: Carvalho e Fernandes (2004); Sobre a Imprensa Periódica Pedagógica ligada ao Movimento da Educaçáo Nova em Portugal, ver Nóvoa (1983a). 
frentes. No ensino infantil, o autor destaca as chamadas missóes móveis, fundadas por Casemiro Freire, que iriam conduzir, já no período republicano, às escolas móveis oficiais destinadas à alfabetização de adolescentes e adultos, sendo estas, segundo o autor, marcadas pelo envolvimento de seus professores na defesa do republicanismo (Fernandes, 1993:160). Acrescenta, ainda, que seria nesse esforço em prol da educação popular que se produziu, no final da década de 1870 , o método de ensino da leitura criado pelo poeta Joáo de Deus, inicialmente testado em escolas noturnas para o ensino de adultos e depois transposto para o ensino infantil.

Em Portugal, o advento da Primeira República permitiu, por sua vez, a criação das Escolas Normais Superiores e das Faculdades de Letras, que se constituíram em importantes focos de inovação pedagógica, segundo o autor. Ele se refere, também, às estratégias educativas substitutivas, representadas por instituiçóes como a Igreja Católica, cujos círculos operários e escolas particulares exerceram vasta influência social e originaram violentos conflitos com as forças anticlericais. Rogério Fernandes avalia, por fim, que o discurso pedagógico republicano depositava desmedida confiança no progresso social, atribuindo à educação e à escola um papel decisivo na consecução das novas metas estabelecidas, concluindo que seu projeto educacional era, por isso, francamente favorável à modernização do sistema educativo.

Entre os intelectuais que se envolveram com o movimento da educação nova em Portugal, alguns nomes têm merecido maior atenção dos pesquisadores. São eles: João de Deus Ramos, Adolfo Lima, Antonio Faria de Vasconcelos e Antonio Sérgio.

Adolfo Lima (1874-1943) exerceu papel de liderança na Escola Oficina no 1 e na Escola Normal de Benfica. Foi diretor da Revista Educação Social (19241927) e foi o primeiro responsável pela seção portuguesa da Liga Internacional Pró Educação Nova, tarefa que assumiu informalmente até a sua prisão em 1927.

João de Deus Ramos (1878-1953) tornou-se professor no Liceu Camôes, em 1902, após terminar o curso de direito em Coimbra. Contribuiu no ensino das primeiras letras, tanto para adultos como para crianças, atuando na regulamentação legislativa, na divulgação de instrumentos de aprendizagem e na criação de instituições.

Antonio Faria de Vasconcelos (1880-1939) é o pedagogo português mais conhecido internacionalmente devido a sua ação na Bélgica, Suíça e América 
Latina. Ele colaborou ativamente nas revistas Seara nova, Educação Popular e Revista Escolar. Participou na elaboração do projeto de reforma João Camoesas $(1923)^{2}$ e do Instituto de Orientação Profissional.

Antonio Sérgio (1883-1969) assumiu, por indicação expressa de Adolphe Ferrière, a direção da seção portuguesa da Liga Internacional Pró Educação Nova no ano de 1927. Produzindo um discurso de fora para dentro do campo educativo, ele empenhou seu prestígio intelectual na difusão de modelos inovadores de ação pedagógica, dando maior credibilidade científica a este movimento. Álvaro Viana de Lemos (1881-1972) é o homem que estabelece as conexôes no seio da educação nova. ${ }^{3}$ Interessante observar as peculiaridades das contribuiçôes dos intelectuais mencionados.

De família aristocrática, Adolfo Lima aderiu à causa anarquista, tendo atuado como diretor da Escola Oficina no 1 , situada em Lisboa. Fundada em 1905 sob inspiração maçônica (republicana e anarquista) para ensinar marcenaria a filhos de operários e trabalhadores em geral, a referida escola se transformou com a entrada de Adolfo Lima e de outros professores anarco-sindicalistas. A partir de entáo, a escola adotou um projeto mais amplo, pautado nas perspectivas de coeducação e autoformação na proposta de educação integral e libertária. A esse respeito, é digno de nota o empenho de Adolfo Lima por definir o projeto adotado na escola em meio ao movimento de inovaçóes pedagógicas em curso à época. Em artigo publicado em 1924, o educador pro-

\footnotetext{
${ }^{2}$ Durante a Primeira República, a chamada Reforma de João Camoesas (1923) constitui uma referência doutrinal, reunindo os ideários pedagógicos da educação nova e da escola ativa. Reforma falhada, o projeto que a sustentava contribuiu, pelo menos, para o debate pedagógico entre os professores e a intelectualidade progressista do período. Cf: Fernandes (1983).

${ }^{3}$ A herança deste movimento e de seus sujeitos é extremamente rica, como reconhecem pesquisadores da área como Fernandes, Nóvoa, Candeias e Figueira. O primeiro publicou livros e artigos sobre o movimento e a contribuição dos atores aqui destacados; os outros três publicaram estudos individuais e coletivos sobre o tema, ressaltando uma publicação que foi muito útil para nossa aproximaçáo com o tema, aqui referenciada várias vezes. Trata-se do livro Sobre a Educação Nova: cartas de Adolfo Lima a Álvaro Viana de Lemos (1923-1941) (1995), que socializa algumas reflexôes a respeito do movimento da educação nova, a partir das correspondências trocadas entre os dois educadores, que constam do espólio de Álvaro de Lemos, preservadas no Movimento da Escola Moderna (MEM). Certamente, as teses de Nóvoa (1987) sobre os tempos dos professores; de Candeias (1981) sobre o movimento operário português e a educação, bem como o roteiro da educação nova em Portugal de Manuel Figueira (2004) são leituras obrigatórias para quem tem interesse no assunto. Por fim, merece registro as obras de referência para o estudo da história da educação portuguesa: A imprensa de educação e ensino: repertório analítico (séculos XIX e XX) e Dicionário de educadores, obras coletivas dirigidas por Antonio Nóvoa (1983).
} 
cura avaliar o funcionamento da escola em relação aos princípios caros à educação nova, tendo como referência os 30 pontos de uma escola nova tipo que circularam nos meios pedagógicos do início do século XX. $\mathrm{O}$ curioso, a nosso ver, é a percepção do autor de que o ideário do movimento da educação nova e o anarquista não eram incompatíveis, destacando muito mais os pontos comuns no que tange à perspectiva de inovação pedagógica e de construção do novo homem que a república poderia viabilizar. Ao final, o autor concluiu que a Escola Oficina não se enquadrava no modelo da educação nova, porém se aproximava deste na crítica à escola tradicional assim como no desejo de mudança e inconformismo para com o estabelecido. De sua contribuição intelectual para o campo da pedagogia, destaca-se a Enciclopédia pedagógica progredir, obra para a qual contou com a colaboração de Álvaro Viana de Lemos.

A contribuição de João de Deus Ramos na militância republicana incluiu o desempenho de cargos públicos ${ }^{4}$ bem como açóes em prol da educação popular. Somando esforços à Associação das Escolas Móveis - empreendimento particular de caráter filantrópico que visava combater o analfabetismo e suprir a ineficiência das instituiçôes educativas monárquicas —, João de Deus Ramos ampliou o escopo desta iniciativa a princípio dirigida apenas aos adultos, incluindo o atendimento à primeira infância, com a criação dos Jardins-Escolas e das Bibliotecas Ambulantes. ${ }^{5}$ Alguns estudiosos consideram que a participação de João de Deus Ramos no projeto das Escolas Móveis para a educação infantil permitiu a criação de um modelo de educação pré-escolar genuinamente português que alcançou relevância e continuidade. Compóe ainda o rol de contribuiçôes do educador a fundação do Museu João de Deus (1917), que se tornou um espaço de debates sobre temas da cultura portuguesa; a fundação de uma Escola Nova portuguesa em 1928, o Bairro Escolar do Estoril, entre outras iniciativas. Sua trajetória incide, portanto, em uma mistura de atuação política e reflexão intelectual temperada pelo engajamento em prol da causa republicana com especial apreço pela educação popular e pela

\footnotetext{
${ }^{4}$ Foi deputado em duas legislaturas pelos círculos de Alcobaça (1911) e de Lamego (1913), governador civil da Guarda (1912) e de Coimbra (1913) e ministro da Instrução Pública (1920) e do Trabalho (1924-1925).

${ }^{5}$ A partir da década de 1910 teve início a criação da rede de Jardins-Escolas João de Deus, totalizando a construção de 11 escolas até sua morte em 1953, com continuidade até os dias atuais, em que atinge mais de 30 unidades escolares. Cf: Barreto (2006).
} 
criação de instituições de ensino modelares, renovadas ou complementares aos modelos já estabelecidos.

Entre essas lideranças, Álvaro Viana de Lemos parece ter oferecido uma contribuição particularmente eficaz no que tange à divulgação do movimento da educação nova, tendo em vista a sua participação em movimentos de cariz sindical (Sindicato de Professores Primários e Uniāo do Professorado Primário, entre outros) e de natureza científico-cultural (Universidades Populares, Liga Internacional de Instrução, Sociedade de Estudos Pedagógicos etc.), bem como sua presença sistemática na imprensa pedagógica da época. Nóvoa (1995:75) destaca a preocupação do educador para com uma intervenção social alargada do professor e nos indica, ainda, as três áreas de reflexão que Álvaro Vieira de Lemos abraçou: 1) a defesa da desburocratização do ensino e da desfuncionarização do professor; 2) a aposta na formação de novos professores e na consolidação de redes de cooperação após a saída deles da escola normal e 3) o investimento no estreitamento de relaçóes entre os trabalhadores do ensino e os trabalhadores manuais, no quadro de afirmação do professor educador.

Os analistas da história da educação portuguesa assinalam que, do grupo, Antonio Sérgio se destaca primordialmente pela contribuição intelectual que deu ao movimento, em razão da extensão de sua obra e pelo impacto e influência de suas ideias. Com base nas observações de Vitor Sá (1979) e de Rogério Fernandes (1983), assim como na leitura do livro Educação cívica, do próprio Antonio Sérgio (1984), foi possível destacar as principais ideias deste autor em relação à educação e a seu papel no projeto de reconstrução da sociedade portuguesa. Em primeiro lugar, se deve destacar que, para Sérgio, as bases da democracia não se encontraram nas instituiçôes políticas e nas leis escritas, mas na estrutura econômica e na educação correspondente. Assim, a criação de um novo estilo de ensino e de um novo tipo de escolas seria, para ele, como havia sido também para muitos intelectuais portugueses da virada do século XIX para o XX, o antídoto natural da decadência nacional. Antonio Sérgio defendeu um modelo de ensino elementar essencialmente prático, fundado muito mais em ações do que em palavras, recusando o ensino retórico e livresco, reservando ao trabalho manual um lugar maior e fazendo tender todos os esforços para a atividade produtora. É, pois, dos próprios ensinamentos colhidos na sua interpretação sociológica da história nacional que ele retira a diretriz da 
renovação pedagógica, que é ao mesmo tempo uma diatribe contra o que ele considerava ser a tradição parasitária do colonialismo português.

Conforme observou Rogério Fernandes (1983), o ensino, para Sérgio, deveria ser indissoluvelmente prático e teórico. Preconizando a ligação entre o ensino e o trabalho produtivo, ele não reclamava o que tradicionalmente se entendia por educação profissional — voltada para formar especialistas —, mas, ao contrário, acentuava a importância da experiência pessoal do educando e de seus interesses intelectuais como bases da educação e da instrução. A pedagogia que preconizava representava, assim, uma pedagogia do trabalho contra a pedagogia da leitura; uma pedagogia da produção contra a armazenagem de conhecimentos; uma pedagogia de ação social, contra a pedagogia das ideias abstratas.

\section{O movimento da educação nova no Brasil}

Para interesse deste estudo, destacaremos duas figuras centrais do movimento da educaçáo nova — Fernando de Azevedo (1894-1974) e Anísio Teixeira (1900-1971). Ambos exerceram liderança nacional, atuando em especial no eixo Rio-São Paulo-Bahia e circulando em âmbito internacional. Ambos tiveram sua formação escolar realizada em colégios jesuíticos, ambos consideraram a possibilidade de seguir o noviciado e ambos formaram-se bacharéis em direito. Estes educadores interferiram na organização do ensino nos primeiros anos republicanos, dirigindo reformas de ensino em estados como Bahia (Anísio Teixeira), Rio de Janeiro (ambos) e São Paulo (Fernando de Azevedo). Nesses cargos, desempenharam papel decisivo na configurarão de uma legislação específica para a educação, bem como nos esforços por aproximar a reflexão sobre a questão educacional dos parâmetros científicos que vigoravam na época.

Tal como observou o próprio Fernando de Azevedo, sua experiência como diretor da Instrução Pública no Distrito Federal (1927-30) se apoiou em um plano de reforma organizado em dois eixos nucleares e interdependentes. São eles: 1) a articulação das diversas instituiçôes educativas e a concordância entre estas e a realidade social e, 2) os princípios modernos de educação em consonância com os pressupostos da educação nova. É, de fato, o desenvolvimento do aspecto social da educação que póe em foco os três princípios fundamentais com base nos quais o educador pretendia conformar o sistema de ensino na 
capital republicana. São eles: o princípio da comunidade (autonomia do sujeito, integração ativa na comunidade); o princípio da escola única (escola cidadã, de formação integral, aberta e igual para todos) e o princípio da escola do trabalho (calcada na experiência do aluno e nos métodos ativos). ${ }^{6}$

Encarando a educação como um problema brasileiro, Fernando de Azevedo esforça-se por definir, no tempo e no espaço, as principais questóes escolares, seus dados e suas soluçóes, procurando conjugar o crescimento individual com o desenvolvimento da sociedade, a formaçáo integral, a valorizaçáo do trabalho e da experiência do aluno. Ele chama atenção para a necessidade de se preparar o professorado a fim de substituir a divisão tradicional dos programas em matérias isoladas pela repartição em complexos agrupados em três grandes seçôes: a natureza, o trabalho e a sociedade. Acrescentou, adiante, que todo sistema de educação depende, antes de qualquer inovação administrativa, da capacidade dos professores de aplicá-las. Segundo Azevedo, a Escola Normal da Capital devia ser reestruturada com suas escolas de experiência e de aplicação, como um centro de estudos e pesquisas pedagógicas, que permitissem aos professores evoluírem em um contínuo aperfeiçoamento.

Consciente do poder de influência exercido pelas iniciativas irradiadas da então capital da República, Azevedo tomou o cargo de diretor da Instrução Pública do Distrito Federal como um importante trunfo para o movimento educacional que se expandia, manifestando a clara intenção de promover uma reforma que servisse de modelo para a organização dos sistemas de ensino dos demais estados da federação. Para tanto reformulou a legislação educacional, entrando em conflito com a Câmara Municipal, por exigir a realização de concurso público como requisito para o ingresso de professores na Escola Normal, contrariando a velha prática de indicação política que até então vigorara.

Com a Revolução de 1930, Fernando de Azevedo foi afastado da Diretoria da Instrução Pública, mas as linhas gerais de seu projeto de reforma tiveram continuidade na gestão de seu sucessor, Anísio Teixeira. Este último entrou na vida pública em 1924, quando recebeu o convite do governador da Bahia, Francisco Marques de Góes Calmon (1874-1932), para ocupar o cargo de inspetor-

\footnotetext{
${ }^{6} \mathrm{O}$ livro Novos caminhos e novos fins: a nova política de educação no Brasil descreve não só os princípios em que se assentava seu plano de reforma como também indica as resistências postas pelo Conselho Municipal (hoje Câmara dos Vereadores), as adesōes de jornalistas e de membros da ABE, assim como as críticas que ele trata de rebater em seus discursos.
} 
-geral do Ensino da Bahia. Teve, nessa ocasião, a oportunidade de realizar a reforma da instruçáo pública, nesse estado, durante os anos de 1924 a 1929.

Em 40 anos de vida pública Anísio Teixeira produziu inúmeros artigos, conferências e relatórios e, em toda a sua produção, o tema da democracia no âmbito da escola e fora dela se impôs sobre outros temas. Por essa ótica, elaborou uma interpretação de conjunto da história, da sociedade e da educação brasileiras ao buscar construir, sobretudo, uma ponte entre a reforma da sociedade pela educação e a renovação cultural desejada, no sentido da plena realização dos ideais republicanos e da democracia, defendendo, para tanto, a educaçấo como um direito de todos.

Podemos identificar com Rocha (2004) quatro ideias centrais que sustentaram o projeto de construção da sociedade democrática e de modernização da esfera educacional defendido por Anísio Teixeira. São elas, as 1) ideias de descentralizaçáo administrativa e de autonomia (da escola e de seus agentes); 2) o reconhecimento do educando (pela percepção de que o processo educativo é, também, um processo individual); 3) o conhecimento da cultura regional (que se insere na própria identidade da escola); e, 4) a atençáo para a fase de desenvolvimento em que se encontrava a cultura nacional.

O empenho em prol da renovação administrativa e pedagógica do aparelho escolar marcou a trajetória de Anísio Teixeira nos diversos cargos e instituiçóes em que atuou, assim como naquelas que ele criou. A prioridade dirigida à educação básica ensejou a compreensão de que a ampliação do tempo de escolarização, articulada a uma proposta pedagógica de educação integral e de profisionalização do magistério, apresentava-se como condição primordial para a melhoria da qualidade da educação pública em nosso país.

No plano da administração pública, ficou clara a oposição de Anísio Teixeira ao processo de racionalização administrativa calcado no modelo padronizador e centralizador montado durante o Estado Novo. Em artigo sobre o assunto, o educador critica o que ele chamou de "equívoco racionalizante" da administraçáo pública brasileira. Ele denunciou a organização monolítica do Estado e a consequente centralização dos serviços, transformados em gigantescos órgãos de controle e fiscalização legal aplicáveis a todos os campos independente do conteúdo e da natureza do setor administrável, resultando na hipertrofia dos meios e processos puramente formais e em oposiçáo aos fins mais gerais a que se destinam os diferentes setores das organizaçôes públicas (Teixeira, 1956). 
A produção escrita de Fernando de Azevedo e de Anísio Teixeira expressa o dinamismo que marcou a atuação de ambos na chamada "reconstrução educacional do país", resultando em uma série de livros, relatórios, documentos administrativos diversos, notícias publicadas pela imprensa diária, correspondências, manifestos públicos etc. A variedade de contribuiçóes deixadas pelos educadores envolvidos nesse movimento nos permite afirmar que, no Brasil dos anos 1920, a história da educação se autoproduziu, avançando no âmbito da implementação de políticas dirigidas à construção de um aparato legal-burocrático para o país e, ao mesmo tempo, se constituindo em registro para a história da educação. $\mathrm{Na}$ confluência entre suas ações e proposições teóricas, eles cuidaram de fazer todos os registros pertinentes, seja em funçáo da necessidade de divulgação, seja em razão da perspectiva modelar que desejavam impor, assumindo o papel de historiadores de sua própria atuação.

Trata-se, portanto, de uma história endereçada aos grupos envolvidos no debate em torno a modelos e diretrizes a serem adotadas pelo Estado em face da reordenação política e institucional ensejada pela proclamação da República. A produção de Anísio Teixeira conta com a presença marcante de relatórios escritos no calor de sua participaçáo nos diversos cargos que desempenhou nas instituiçôes de educação e de pesquisa, sendo composta, também, por ensaios, discursos, palestras. Um bom exemplo dessa particularidade das publicaçôes de Anísio é o livro $A$ Educação e o mundo moderno. Reunindo conferências e contribuiçôes a congressos e reuniôes, o autor assume abertamente a dimensão utópica que permeia suas reflexóes e reafirma sua crença na democracia e no desenvolvimento científico, como motores da capacidade imaginativa dos homens na solução de seus problemas e na superação de suas perplexidades (Teixeira, 1977:3).

Em relação a Fernando de Azevedo, merece registro sua produção monumental: A cultura brasileira (1958), na qual o autor traça os caminhos do processo de institucionalização da educação escolar, do ensino universitário e das instituiçôes promotoras do desenvolvimento científico. Fica claro, nessa obra, o papel atribuído aos processos de institucionalização da educação, das ciências e da cultura no traçado da história nacional. Nessa mesma linha, se desenvolvem as análises que integram outro livro por ele organizado e publicado em 1955. O livro reúne artigos de autores de diferentes áreas de saber no 
intuito de compor um amplo panorama do desenvolvimento histórico d'As ciências no Brasil.

Rocha (2004:14) observa que a questão educacional na Primeira República surge justamente de uma reflexão política sobre a fragilidade dos processos decisórios que excluíam a participação do povo sem instrução. Porém, se os vezos autoritários se fazem presentes de modo mais ou menos intenso na percepção da insuficiência do povo para o exercício da cidadania, essa mesma percepção terá como contraponto a expectativa de redenção da população a ser viabilizada por meio da universalização da educação escolar. É essa crença que dará o tom utópico do projeto político-pedagógico dos pioneiros da educação nova, incidindo sobre o estilo por vezes triunfalista da escrita da história da educação por eles desenhada.

Torna-se relevante lembrar o diálogo que alguns deles, particularmente Anísio Teixeira, estabeleceram com intelectuais do porte de Sérgio Buarque de Holanda e Gilberto Freyre, por exemplo, buscando explicaçôes para as limitações já evidenciadas nos balanços sobre as políticas de governo das quais participaram no âmbito das reformas de ensino dos anos 1920-30. O grande desafio consistiu em superar a distância verificada na dinâmica das instituiçóes de ensino em relação às particularidades culturais das comunidades nas quais se inseriam. $\mathrm{O}$ eixo condutor dessa empreitada foi a busca por compreender os fundamentos da construção nacional, inquirindo a tradição ibérica — rural e patrimonial que nos foi legada pelo colonizador - e confrontando-a com as possibilidades abertas pelo capitalismo norte-americano - com a constituição da sociedade de massas, moderna e impessoal, mas que rapidamente se torna, também, uma sociedade dos individuos. No diálogo entre modelos de civilização, tentaram captar as manifestaçôes características das culturas regionais do Brasil de modo a construir uma relação mais orgânica entre escola e comunidade, buscando, nesse empenho, captar os traços genuinos da cultura nacional (Freitas, 2002).

\section{Considerações finais}

Conforme pudemos observar, as aproximaçôes entre o ideário republicano e as bandeiras do movimento da educação nova nos remetem a movimentos de contestação aos modelos dominantes na virada do século XIX para o XX, 
seja no âmbito da organização política, seja no que tange aos modelos de organização das instituiçôes escolares. A virada política, com a introdução dos governos representativos, as expectativas, ainda que limitadas, de ampliação da participação popular nos processos eleitorais e a secularização da cultura estavam a requerer a ampliação do acesso à escola. Por meio desta instituição, eles esperavam promover o acesso à cultura letrada e ao raciocínio racional, o que, em última instância, viabilizaria a participação dos indivíduos nas instâncias formais de inclusão social, de participação política e de ocupação profissional.

A perspectiva de romper com os modelos padronizados e impessoais que nortearam a construção do modelo escolar na transição do século XIX para o XX expressam, a nosso ver, uma perspectiva de aprofundamento das mudanças em curso nas sociedades ocidentais, acompanhando a transição ocorrida no campo político, com a queda dos regimes monárquicos e aristocráticos e a imposição dos regimes republicanos com todas as implicaçóes culturais daí decorrentes.

No Brasil como em Portugal, a estreita vinculação entre projeto educacional e projeto de sociedade expressam a inquietação que levou os intelectuais dessa geração de republicanos a empreender a busca constante de compreensão dos problemas nacionais. Eles acreditavam que a formulaçáo de um projeto educacional adequado às peculiaridades nacionais seria capaz de reorientar os rumos da nação, modificando mentalidades e introduzindo novos hábitos e valores favoráveis à superação de uma panaceia de problemas. Estes problemas poderiam incluir desde a decadência econômica e a tradição parasitária (identificada por Antonio Sérgio) até a distância cultural (assinalada por Anísio Teixeira) que cindia a sociedade brasileira entre uma elite esclarecida e um povo visto como ignorante e doente, afetando o funcionamento das instituiçóes republicanas, entre elas, as escolas.

A experiência portuguesa e brasileira, levadas a efeito pelas lideranças do movimento da educação nova, indica, para os primeiros, a ênfase em experiências localizadas em instituiçôes específicas, como alguns liceus, e em escolas de formação de professores modelares, ao lado de políticas complementares no âmbito da educação infantil, com as escolas móveis e os esforços de ampliação do acesso ao conhecimento formal, com as universidades populares.

No contexto brasileiro, os educadores filiados ao movimento da educaçáo nova atuaram em, pelo menos, três espaços distintos, porém articulados, de 
ação - as reformas do ensino nos estados, a criação de universidades e a criação de instituiçóes ligadas à burocracia estatal. Desse modo, eles procuraram garantir a reprodução de uma geração de intelectuais envolvidos com a problemática educacional, instrumentalizando-os para pensar tal problemática com base em parâmetros de racionalidade e em atenção com os problemas nacionais.

Entre os educadores portugueses também se destacam as preocupações para com a qualificação dos professores, não só no âmbito das escolas de formação, mas, também, na organização de um conjunto de estratégias associativas que visavam manter vivas as bandeiras da renovação educacional, assim como estabelecer procedimentos duráveis, tanto na trajetória individual dos professores quanto em suas açóes coletivas. $\mathrm{O}$ vigor do movimento associativo docente parece constituir um dos resultados profícuos do movimento da educação nova em Portugal. Talvez com isso as lideranças do movimento quisessem compensar as dificuldades postas pela instabilidade política que marcou a Primeira República portuguesa, dificultando a continuidade dos projetos de reforma do ensino assim como de uma ação coordenada em nível nacional e operada por dentro do aparelho de Estado.

Para Rogério Fernandes (1983), a Ditadura teria bloqueado as perspectivas de inovação educacional, na medida em que seus principais arautos foram levados à prisão, à marginalização ou ao exílio. Porém, conforme observou Antonio Nóvoa (1995), a partir de 1930 se descobre uma nova imagem da educação nova, conectada com correntes pedagógicas religiosas e conservadoras, além da apropriação ensaiada pelos nacionalistas, o que só se torna possível mediante a mudança de perspectiva sociopolítica do movimento e ao esvaziamento das potencialidades pedagógicas transformadoras da Educação Nova.

Tal como em Portugal, também no Brasil se deu a apropriaçáo de alguns princípios do movimento da educação nova pelos católicos, por um lado, assim como pelos educadores filiados a posiçóes autoritárias e à tecnocracia, por outro. Tais modos de apropriaçáo das concepçóes e experiências do movimento da educação depuraram o sentido político original de seus propósitos, lançando sobre o movimento e sobre suas lideranças um tratamento ambíguo no que tange à avaliaçáo de seu legado histórico.

Nesse caso, os historiadores da educação se dividiram entre aqueles que reproduzem a versão monumentalizada do papel desse movimento na orga- 
nização do Brasil republicano e aqueles que se preocuparam, em um primeiro momento, em combater essas ideias e, em um segundo momento, em recusar as narrativas de suas lideranças, considerando que, com isso, estariam adotando uma atitude mais racional na construção da interpretação desse legado histórico.

Ao longo da história, as avaliaçôes a respeito da contribuição do movimento da educação nova para o projeto de construção do país em moldes republicanos oscilou entre acusações e apologias. Esses educadores foram acusados de comunistas, integralistas e absolutistas, no contexto dos anos 1920 e 1930; em seguida, no contexto dos anos 1950-60, foram vistos como utópicos e equivocados em relação às reais condiçóes do país; nos anos 1970, no auge do regime militar brasileiro, eles foram qualificados de tecnocratas a serviço dos interesses do Estado e, em última instância, da hegemonia burguesa. Nos anos 1980-90, seu legado histórico foi retomado no curso do processo de redemocratização pós-ditadura militar, sendo reinterpretados sob o influxo da difusão dos modos de abordagem sugeridos pela história cultural.

Encerramos nossas reflexôes ressaltando que a experiência histórica do movimento da educação nova ainda se faz presente no debate educacional contemporâneo, provavelmente porque os nexos deste movimento pedagógico com a vida republicana ainda merecem um lugar de relevo na pauta de debates das questôes nacionais. Ao mesmo tempo, por terem sido incorporadas nos diversos contextos nacionais a partir de modelos e de dinâmicas que se difundiram em nível mundial, as concepçóes e experiências do movimento da educação nova expressam lógicas e racionalidades que se situam para além das fronteiras de cada país, bem como extrapolam os contextos temporais nos quais foram forjadas, projetando utopias e aspiraçóes por mudanças que seguem sendo partilhadas nos dias atuais.

\section{Referências}

AZEVEDO, Fernando de. A cultura brasileira. 4. ed. São Paulo: Melhoramentos, 1964.

. (Org.). As ciências no Brasil. 2. ed. Rio de Janeiro: Ed. UFRJ, 1994. . Novos caminhos e novos fins. São Paulo: Melhoramentos, s.d. 
BARRETO, Graziela. João de Deus Ramos e a Educação Nova. In: PINTASSILGO, Joaquim et al. História da escola em Portugal e no Brasil: circulação e apropriação de modelos culturais. Lisboa: Ediçôes Colibri, 2006. p. 111-140.

BOBBIO, N.; MATEUCCI, N.; PASQUINO, G. (Org.). Dicionário de política. Brasília: UnB, 1991. p. 1107-1109.

CANDEIAS, António. Educar de outra forma: a Escola Oficina № 1 de Lisboa, 1905930. Tese (doutorado) — Universidade do Porto, Porto, 1994. 2 v.

CARVALHO, L.M.; FERNANDES, Ana Lúcia Cunha. O conhecimento sobre a educação e os problemas nacionais: os Congressos Pedagógicos da Liga Nacional de Instrução (Lisboa, 1908-1914). 20. ed. Lisboa: Educa, 2004. v. 24.

CARVALHO, Marta. Molde nacional, forma civica: higiene, moral e trabalho no projeto da Associação Brasileira de Educação. Bragança Paulista: Edusf, 1998.

FELGUEIRAS, Margarida; MENEZES, Maria Cristina (Org.). Rogério Fernandes: questionar a sociedade, interrogar a história, repensar a educação. Porto: Ediçóes Afrontamento, 2004.

FERNANDES, Rogério. Antonio Sérgio: ministro da Instrução Pública. Revista História das Ideias, Coimbra, t. II, v. V, p. 603-700, 1983.

História das inovações educativas (1875-1936). In: NÓVOA, A.; BÉRRIO, J.R. (Org.). A história da educação em Espanha e Portugal. Lisboa: Sociedade Portuguesa de Ciências da Educação, 1993. p. 156-170.

FIGUEIRA, Manuel Henrique. Um roteiro da educação nova em Portugal. Lisboa: Livros Horizonte, 2004.

FREITAS Marcos Cezar de. O centenário de Sérgio Buarque de Holanda diz respeito à história da educação brasileira. Uma saudação. Horizontes, Bragança Paulista, p. 9-13, jan./dez. 2002.

NÓVOA, António (Dir.). A Imprensa de educação e ensino: repertório analítico (séculos XIX-XX). Lisboa: Instituto de Inovação Educacional, 1983a.

. (Dir.). Dicionário de educadores. Lisboa: Ministério da Educação/Biblioteca Nacional, 1983 b.

. Les temps des professeurs. Lisboa: Instituto Nacional de Investigação Científica, $1987.2 \mathrm{v}$.

. Uma educação que se diz nova. In: CANDEIAS, A.; ; FIGUERIA, M. (Orgs.). Sobre a Educação Nova: cartas de Adolfo Lima a Álvaro Viana de Lemos (1923-1941). Lisboa: Educa, 1995.

NUNES, Clarice. Anísio Teixeira (verbete). In: FÁVERO, M.L.A.; BRITTO, J.M. (Org.). Dicionário de educadores brasileiros: da colônia à república. Rio de Janeiro: Ed. UFRJ, 2002. p. 79-80. 
PINTASSILGO, Joaquim. República e formação de cidadãos. Lisboa: Ediçôes Colibri, 1998.

PINTO, Antonio Costa (Coord.). Portugal contemporâneo. Lisboa: Publicações Dom Quixote, 2005.

ROCHA, Marlos Bessa Mendes da. Matrizes da modernidade republicana: cultura política e pensamento educacional no Brasil. São Paulo: Autores Associados; DF: Editora Plano, 2004.

SÁ, Victor. A historiografia sociológica de Antonio Sérgio. Lisboa: Biblioteca Breve, 1979. SÉRGIO, Antonio. Educação cívica. Lisboa: Ministério da Educação, 1984.

TEIXEIRA, Anísio. A educação e o mundo moderno.São Paulo: Editora Nacional, 1977. A administração pública brasileira e a educação. Revista Brasileira de Estudos Pedagógicos, Rio de Janeiro, v. 25, n. 61, p. 3-23, jan./mar. 1956. 